\title{
A Study on the Evaluation of Flow Distribution Evenness in Parallel-Arrayed Type Low Pressure Membrane Module Piping
}

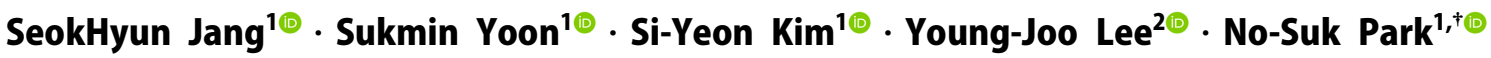 \\ 'Department of Civil Engineering and Engineering Research Institute, Gyeongsang National University \\ ${ }^{2} \mathrm{~K}$-water Research Institute
}

(Received March 18, 2021; Revised April 8, 2021; Accepted May 6, 2021)

Objectives: In this study, the degree of uniformity of the flow rate flowing into each module is measured for the external pressure typed low-pressure membrane (microfiltration) filtration process that has been actually applied to water treatment, and computational fluid dynamics (CFD) technique is used to clarify the cause and effect.

Methods: Mobile ultrasonic flow meter was used to measure the flow rate flowing from the membrane module pipe to each module, and the CFD technique was used to verify this.

Results and Discussion: From the results of the actual measurement using ultrasonic flowmeter and CFD simulation, it was confirmed that the outflow flow rate from the branch pipe located at the end of the header pipe was three times higher than that of the branch pipe near the inlet. The reason was that the differential pressure generated between each membrane module was higher toward the end of the header pipe.

Conclusions: When the ratio of the sum of the cross-sectional area of the branch pipe and the cross-sectional area of the header pipe was reduced by about 30 times, it was confirmed that the flow rate flowing from each branch pipe to the membrane module was almost equal. Also, If the flow in the header pipe is transitional or laminar (Reynolds No. is approximately 4,000 or less), the flowrate flowing from each branch pipe to the membrane module can be more even.

Keywords: Flow Distribution Evenness, Membrane Module, Manifold Pipe, Ultrasonic Flowmeter, CFD 


\title{
연구논문
}

\section{병렬 설치형 저압막 모듈 배관의 유량 균등 분배 평가에 관한 연구}

\author{
장석현 $^{1 \oplus} \cdot$ 윤석민 $^{1 \oplus} \cdot$ 김시연 $^{1 \oplus} \cdot$ 이영주 $^{2 \oplus} \cdot$ 박노석 $^{1+\oplus}$ \\ ${ }^{1}$ 경상국립대학교 토목공학과 및 공학연구원 \\ ${ }^{2} \mathrm{~K}$-water 연구원
}

목적 : 본 연구에서는 실제 정수처리에 적용되고 있는 외압식 저압막(정밀여과막, Microfiltration) 여과 공정을 대상 으로 각 모듈로 유입되는 유량의 균등 정도를 실측하고, 전산유체역학(Computational Fluid Dynamics, CFD)를 이 용하여 그 원인을 밝히고자 하였다.

방법: 본 연구에서는 막 모듈배관에서 각 모듈로 유입되는 유량을 측정하기 위해 이동형 초음파 유량계를 사용하 였으며, 이를 검증하기 위해 전산유체역학 기법을 이용하였다.

결과 및 토의: 초음파 유량계를 이용한 실측과 CFD 모사 결과로부터 헤더 배관 끝단에 위치한 분지관으로부터의 유출 유량이 유입구 근처의 분지관 유량보다 3 배 높았다. 그 이유는 각 막 모듈 사이에서 발생하는 차압이 헤더 파이프 끝으로 갈수록 더 높았기 때문이다.

결론 : 지관의 단면적의 합과 헤더 배관의 통수 단면적의 비를 약 80 배 정도 감소할 경우 각 분지관에서 막 모듈로 유입되는 유량이 거의 균등한 것을 확인 할 수 있었다. 또한 관내 흐름이 천이류 및 층류인 경우(Reynolds No.가 대략 4,000 이하) 각 분지관에서 막 모듈로 유입되는 유량을 균등화 시킬 수 있을 것으로 판단할 수 있다.

주제어: 유량 균등 분배, 막모듈, 다지관, 초음파유량계, 전산유체역학

\section{1. 서론}

정수처리 시스템에 적용하고 있는 정밀여과(Microfiltration) 및 한외여과(Ultrafiltration) 등의 병열 배치형 저압막 공정은 막 세공(pore) 전·후단의 차압을 이용하여 세공보다 큰 입자 성 오염물질을 체거름(straining) 기작에 의해 선택적으로 제 거한다. ${ }^{1,2)}$ 그러나 막여과 공정은 공극의 크기에 따라 입자성 물질, 유기물질, 무기염 등의 제거가 가능하고 안정적인 수질 의 물을 생산할 수 있어 다양하게 활용되는 기술이다. ${ }^{3,4}$ 그러 나 막여과 기술의 많은 장점에도 불구하고 막여과 공정은 운 전시간 경과에 따른 여과효율 감소, 즉 막오염(Membrane fouling) 현상이 발생하여 막여과 기술의 수처리 분야 도입에 주요 문제점으로 언급되어왔다.,3-6) 일반적으로 저압막은 아 래 부분 헤더(Header) 배관을 중심으로 병렬로 설치된 각 막 모듈로 처리 대상수가 유입되고 막을 통해 고액 분리된 여과 수가 상부로 모여서 유출되는 구조를 가지고 있다(Fig. 1). 하부의 상대적으로 큰 헤더 배관으로부터 상향으로 설치된 다지관(manifold pipes)를 통해 병렬로 설치된 막 모듈로 처리 대상수가 유입되는 구조를 가지고 있다.,2) 이러한 구조는 열
역학 냉각분야에서 많이 적용되어 왔는데, 냉매를 균등하게 냉각 대상에 유입시키기 위한 방안이 1990년대 초부터 Shen, Choi 등 및 Datta와 Majumdar에 의해 제안되었다. ${ }^{7-9)}$ 그들은 모두 다지관과 헤더 배관의 통과 단면적의 비가 작을수록 균 등한 유량분포가 나타남을 실험적으로 제안하였다. 또한 Eguchi 등은 다지관과 헤더 배관의 단면적의 비가 작을수록 손실계수가 작아지는 장점을 밝혀냈다. ${ }^{10)}$

그러나 이러한 방안을 수처리에 적용되는 막 공정에 적용하 기에는 무리가 있다. 상용되는(commercial) 저압막 모듈의 유 입구(다지관의 직경)의 직경은 대부분 $50 \mathrm{~mm}$ 이상으로 정해 져 있기 때문에 연결되는 분배 다지관의 단면적과 헤더 배관 의 비를 작게 하는 데는 제한이 있으며, 비를 작게 하는 경우 손실수두가 커져 에너지의 소모가 커지는 문제가 있다. 본 연 구에서 이를 검토한 결과와 실제 운전 중인 막 여과 공정을 대상으로 유량을 균등화시키기 위해 필요한 지관과 헤더 배관 의 비를 제시하고자 하였다.

Hong과 Riggs는 수치해석을 통해 단면적이 점점 축소되는 헤더 배관(Tapered header)이 단면이 일정한 분배관보다 균일 한 유속분포를 얻으며 이에 동수압이 일정해짐을 강조하였 
다. ${ }^{11)}$ 그러나 이러한 방법은 헤더배관의 유속이 상대적으로 낮은 경우 적용 가능하다. 실제 수처리용 막여과 공정에 적용 되는 헤더 배관의 경우 일반적으로 $1.0 \mathrm{~m} / \mathrm{s}$ 이상의 유속을 유 지하도록 설계 및 운전하고 있는데, 그 이유는 헤더 배관 내 혹시 발생할 수 있는 입자의 침전을 방지하기 위함이다. Muhana와 Novog는 다지관이 설치된 헤더 배관을 대상으로 헤더 배관의 유속과 Reynolds No.가 다지관을 통해 유입되는 유량에 미치는 영향에 대해 조사하였는데, Reynolds No.가 증 가할수록 헤더 배관 유입구로부터 먼 측의 다지관으로 유입되 는 유량이 증가함을 실험적으로 밝혔다. ${ }^{2)}$ 헤더 배관이 관수 로임을 고려하여 본 연구에서 헤더 배관에서의 Reynolds No. 와 다지관 유량의 균등 정도와의 관계를 밝히고자 하였다.

한편 2000년대 후반부터 전산유체역학(Computational Fluid Dynamics, $\mathrm{CFD}$ )기법을 이용하여 다지관이 적용되는 분야에 서 설계 최적화를 도모하는 연구들이 나타났다. ${ }^{1)}$ Ding은 모듈 화되어 있는 막 시스템을 대상으로 $\mathrm{CFD}$ 와 검증실험을 통해 헤더 배관으로부터 각 막 모듈로 유입되는 유량에 많은 편차 가 발생함을 조사하였다. ${ }^{13)}$ 또한 Paul 등은 양성자 교환막 연 료 전지 스텍(Stack)에 있어서 병렬로 배열된 단위 셀(cell)로 유입되는 유체 유량이 유출 헤더의 흐름 방향과 연관이 있음 을 $\mathrm{CFD}$ 로 모사한 바 있다. ${ }^{14)}$ 이상과 같이 1990년대 후반부터 헤더 배관과 다지관의 유량분배가 다수 진행되었지만 대부분 연료 전지 및 에너지 공학 분야의 성과이며, 수처리 분야에서 의 막 모듈 배관 관련 연구는 거의 전무한 상태이다.

이에 본 연구에서는 실제 운영 중인 정수처리 막여과 공정 을 대상으로 헤더배관에서 병열로 설치한 각 모듈로의 유량 분배를 양상을 이동형 초음파 유량계로 실측하고, $\mathrm{CFD}$ 기법을 이용하여 유량 불균등 분배의 원인을 규명하고자 하였다. 그 리고 앞서 언급한 바와 같이 동일 막 여과 공정을 대상으로 유량을 균등화시키기 위해 필요한 지관과 헤더 배관의 비를 제시하고자 하였다. 마지막으로 헤더 배관에서의 Reynolds No.와 다지관 유량의 균등 정도와의 관계를 밝히고자 하였다.

\section{2. 연구 방법}

\section{1. 대상 막 여과 시설 개요}

본 연구에서 대상으로 정한 막 여과시설은 계획급수량이

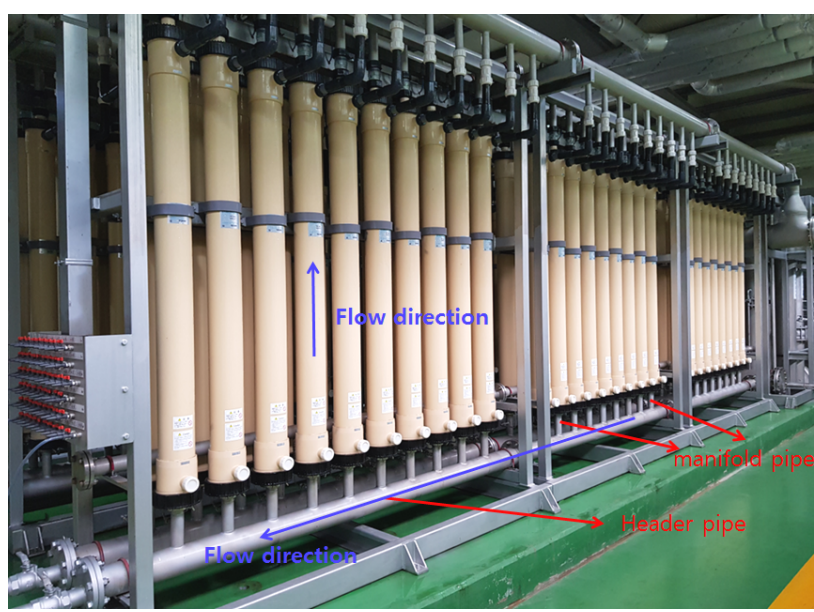

Fig. 1. Actual parallel-arrayed membrane module for drinking water treatment.

Table 1. The membrane module specifications.

\begin{tabular}{|c|c|}
\hline Membrane manufacturer & Asahi Kasei \\
\hline Membrane type & Microfiltration (MF) \\
\hline Membrane module shape & $\begin{array}{l}\text { External pressure type hollow } \\
\text { fiber membrane (casing) }\end{array}$ \\
\hline Hollow fiber & Inner D 0.7 mm/external D $1.2 \mathrm{~mm}$ \\
\hline Pore size & $0.1 \mu \mathrm{m}$ \\
\hline Membrane material & PVDF \\
\hline Flux (pure water) & $\begin{array}{c}1^{\circ} \mathrm{C}: 3.26 \mathrm{~m}^{3} / \mathrm{m}^{2} \cdot \text { day } \\
25^{\circ} \mathrm{C}: 6.38 \mathrm{~m}^{3} / \mathrm{m}^{2} \cdot \text { day }\end{array}$ \\
\hline Module size & 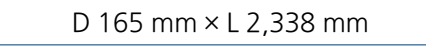 \\
\hline Membrane area & $50 \mathrm{~m}^{2} /$ module \\
\hline Allowable pressure & $300 \mathrm{kPa}$ \\
\hline Allowable $\mathrm{pH}$ & $0 \sim 12$ \\
\hline
\end{tabular}

$27,000 \mathrm{~m}^{3} /$ 일 인 국내 K_정수장 내 위치하고 있다. 막의 제원 은 다음 Table1과 같으며 막 모듈은 정밀여과막이다. 막 여과 유속(Flux)은 $1.0 \mathrm{~m}^{3} / \mathrm{m}^{2} \cdot$ 일 $\left({ }^{\circ} \mathrm{C}\right)$ 이며, 현재 6 계열로 설치되어 운전 중이다. 1 개의 헤더 배관에 설치된 막 모듈은 총 28 개이 다(Fig. 1 및 2 참조). 약품 세척은 CIP (Clean in Place Instructions)로 하고 있다. 막여과 운영은 수세 1 분, 여과 35 분 그리고 역세 1 분으로 이루어지고 있다.

다음 Fig.2는 Fig. 1 의 하부 유입 헤더 배관만을 형상화한
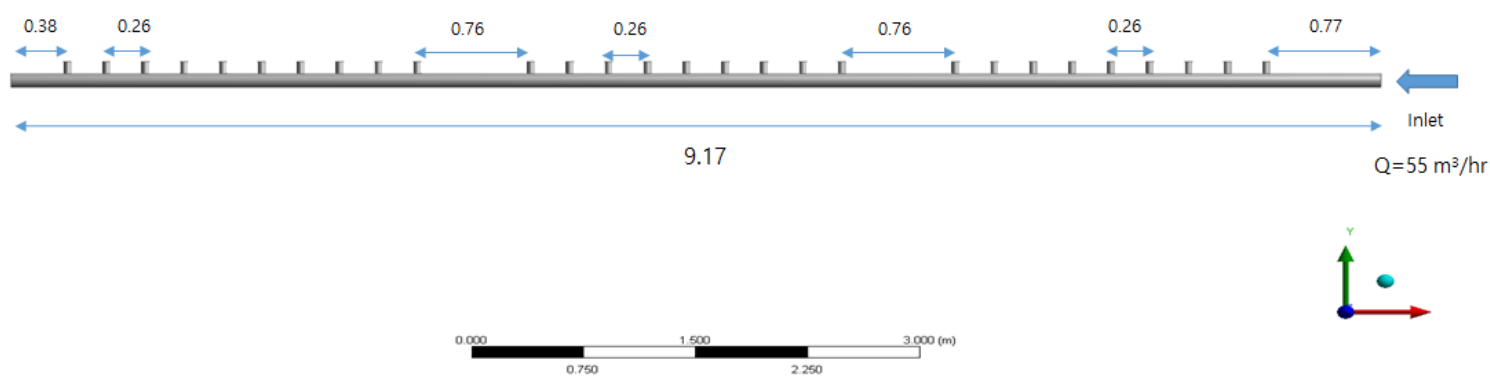

Fig. 2. Geometry of inlet header and manifold pipes (unit: $m$ ). 


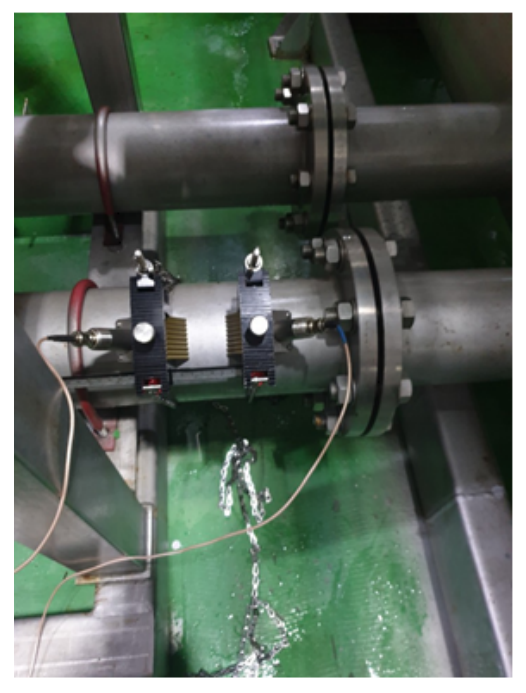

(a) sensor and transducer (clamp-on type)

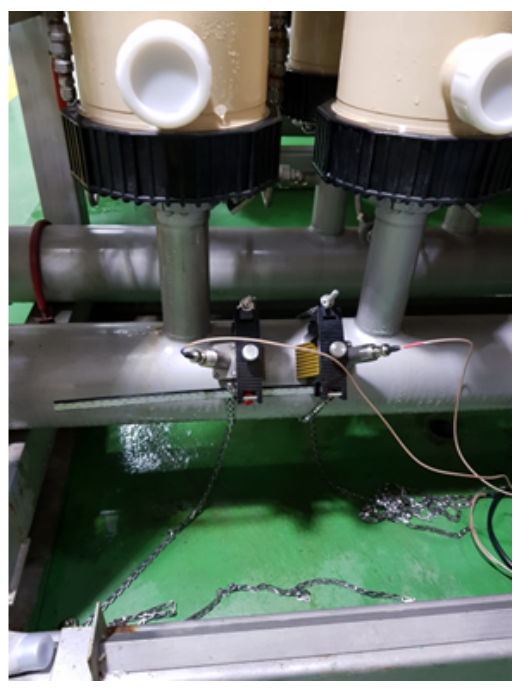

Fig. 3. Clamp-on transducers and ultrasinic liquid flowmeter for this research.

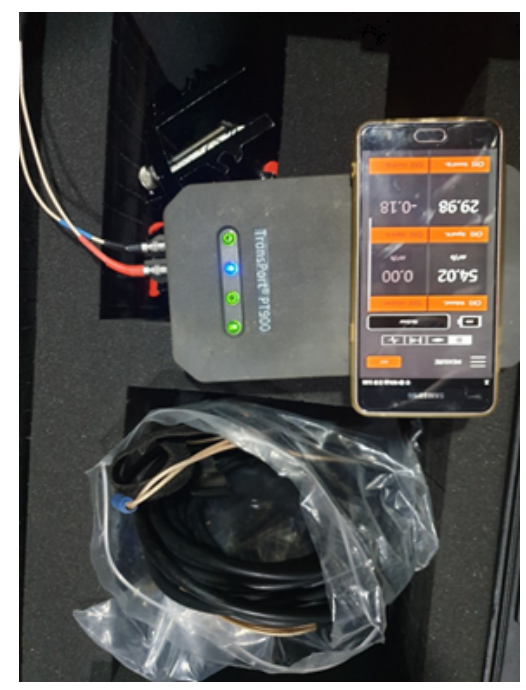

(b) Flow meter

Table 2. Ultrasonic flow meter and transducer specifications.

\begin{tabular}{cccc} 
Flow meter & PT878 & Transducer type & Clamp-on \\
Flow type & All acoustically conductive fluids & Applications & Liquid \\
\hline Pipe size & $12.7 \mathrm{~mm} \sim 7.6 \mathrm{~m}$ & Compatible meters & PT878 \\
\hline Pipe wall thickness & Up to $76.2 \mathrm{~mm}$ & Frequency & $1 \mathrm{MHz}$ \\
\hline Pipe materials & All metals and most plastics & Process temp. & $-20 \sim 210^{\circ} \mathrm{C}$ \\
\hline Repeatability & $\pm 0.1 \%$ to $0.3 \%$ of reading & Ambient temp. & $-20 \sim 40^{\circ} \mathrm{C}$ \\
\hline Range & -12.2 to $12.2 \mathrm{~m} / \mathrm{s}$ & Materials of construction & Metals and plastics \\
\hline Rangeability & $400: 1$ & & \\
\hline Measurement parameters & Volumetric flow, totalized flow and flow velocity & & \\
\hline
\end{tabular}

것이다. 유입부(inlet)로부터 $0.77 \mathrm{~m}$ 위치에서 9 개의 막 모듈 이 설치되고, 다시 9 번째 모듈에서 10 번째 모듈 사이에는 0.76 $\mathrm{m}$ 의 거리가 있다. 이후 18 번째 모듈과 19 번째 모듈에서 0.76 $\mathrm{m}$ 의 거리를 두고 있다. 하나의 유입 헤더 배관 기준(unit) 일평 균 운전 유량은 $55 \mathrm{~m}^{3} / \mathrm{hr}$ 정도이다.

\section{2. 초음파 유량계를 이용한 유량 분배 실측}

본 연구에서는 건식(Clamp-on type)의 초음파 유량계를 사 용하여 각 모듈로 유입되는 유량을 실측하였다. 초음파의 특 성을 이용하여 관로 내 유량을 측정하는 것이 초음파 유량계 이다. 최근에는 습식(wetted type) 방법보다 건식 방법이 설치 가 용이하고 배관의 훼손이 없어 관리가 쉽기 때문에 적용 분야가 넓어지고 있는 상황이다.

습식은 건식에 비해 정확도가 상대적으로 좋지만 설치 및 이동성이 좋지 않아 건식 방법을 선호하고 있다. 건식 방법은 transducer가 외벽에 부착되어 있어(Fig.3 참조) 유속을 계산 할 때 온도에 따른 음속의 영향이 유속 계산에 미치는 영향을 배제하기 위해 역수차법을 사용하고 있다. 다음 Table 2는 본 연구에서 사용한 transducer와 flow meter의 사양을 정리한 것
이다.

정확한 유량 값을 측정하기 위해서는 곡관부에서 $5 \mathrm{D}$ 이상 의 거리를 두어야 한다. ${ }^{15)}$ 그러나 본 연구의 대상이 되는 막 모듈 유입 헤더 배관의 경우 지관사이의 거리가 $0.26 \mathrm{~m}$ 정도 밖에 되지 않는다. 이에 정확한 유량 값을 얻기에는 무리가 있어 Fig.3(a)와 같이 헤더 배관에서 직접 유량 값을 읽고 각 지관을 지나면서 발생하는 유량의 변화량을 그 지관의 유입 유량이라 간주하는 방법을 사용하였다. 측정결과에서 언급하 겠지만 다소 유량 값이 안정적이지 않았지만 설치 후 약 5 분 후 안정화되는 값을 얻었다.

\section{3. 실험데이터의 통계 처리}

앞서 언급한 것과 같이 $\mathrm{K}$ 정수장은 6 개의 개열로 구성되며, 유입 헤더 배관 기준(unit) 일 평균 운전 유량은 $55 \mathrm{~m}^{3}$ 일 이다. 하지만 실제 관측에 있어서는 운영조건의 변화에 따라 각 계 열별 유입유량이 일정하지 않아 계열별 지관유량의 분포를 직접적으로 비교·분석하기는 어렵다. 따라서 본 연구에서는 초음파 유량계로부터 획득된 각 계열별 지관 유입유량에 대한 정량적 평가를 수행하기 위해 최소-최대 정규화를 활용하였 
다. 즉, 막공정의 한 모듈에서 각 지관으로 유입되는 유량 $X=\left[x_{1}, x_{2}, \ldots, x_{n}\right]$ 들에 대해 최대값 $x_{\max }$, 최소값 $x_{\min }$ 을 산정 하고, 식(1)의 절차를 통해 지관 유입유량을 정규화 하였다.

$$
z_{i}=\frac{x_{i}-x_{\min }}{x_{\max }-x_{\min }}
$$

그리고 각 계열에서 정규화된 지관유량의 분포를 분석하기 위해 지관의 무차원 거리 및 정규화된 유입유량을 활용해 선 형회귀분석을 수행하였다. 여기서, 지관의 무차원 거리는 첫 번째 지관의 위치를 원점으로 설정한 후 각 지관까지 측정된 상대거리를 의미한다. 그리고 선형회귀 모형의 형태는 각 지 관의 유량균등 분포를 분석하기 위해 설명변수로서 무차원거 리, 반응변수로서 표준화 유량을 입력하였다.

\section{4. 전산유체역학 모사 방법론}

\subsection{1. 형상 작업 및 경계 조건}

본 연구에서는 헤더 배관 및 다지관의 내부 유체 거동을 전산 유체역학(CFD)기법으로 모사하기 위해 상용코드인 ANSYS CFX16.0을 사용하였다. Fig.4는 유동해석을 수행할 다지 헤 더 배관의 형상을 나타내었다(Fig.4(a)). Fig.4(b)는 헤더 배 관의 직경을 $0.12 \mathrm{~m}$ (Fig.4(a))에서 $1.073 \mathrm{~m}$ 로 증가시켜 다지

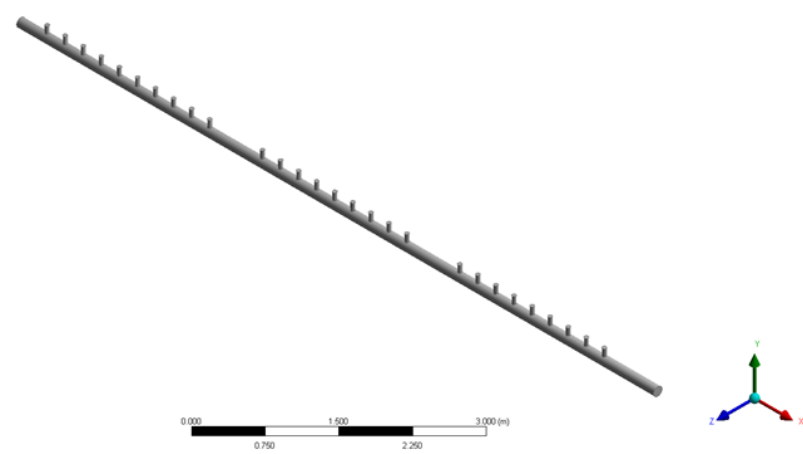

(a) Actual manifold pipe $\left(\frac{\sum a}{A}=4.861, a\right.$ : branch pipe cross-sectional area, $A$ : header pipe cross-sectional area)
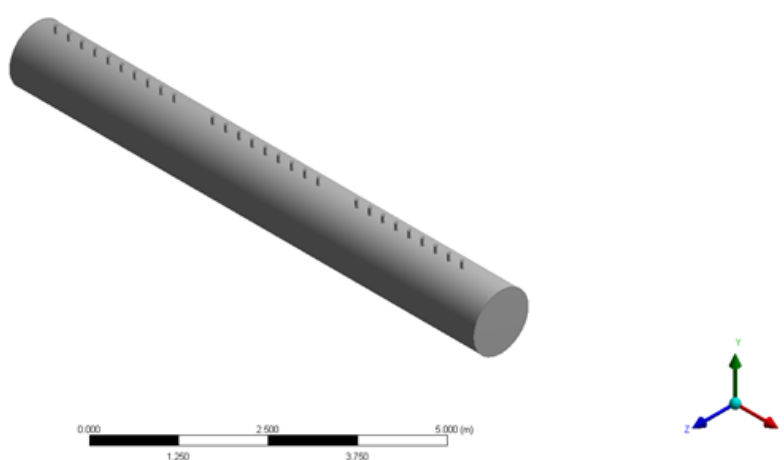

(b) manifold pipe with enlarged diameter $\left(\frac{\sum a}{A}=0.061\right)$

Fig.4. Geometry of manifold pipes.
관 면적의 합과 헤더 배관의 단면적의 비를 4.861 에서 0.061 으로 변화 시킨 것이다. 앞서 선행 연구에서 언급한 바와 같이 다지관의 면적의 합과 헤더 배관의 단면적의 비를 감소시킬 경우 유량의 균등화를 제고시킨다는 가정 하에 약 80 배 정도 감소시킨 경우 유량의 균등 분배를 도모할 수 있는 것을 알 수 있었다. 연구 결과에서 다시 언급하겠지만 헤더 배관의 관 경을 조금씩 증가시키면서 trial and error를 통해 찾아낸 면적 비이다.

배관의 길이는 (a)와 (b)의 경우 모두 $9.17 \mathrm{~m}$ 이며, 분지관의 사이의 간격 및 직경 또한 동일하다. 분지관의 직경은 $50 \mathrm{~mm}$ 이며, 분지관 유출구의 방향은 상향이다. 본 CFD 모사는 정상 상태를 가정하였으며, 유동장으로 흐르는 유체의 특성은 상온 상태를 고려한 $25^{\circ} \mathrm{C}$ 의 물이 유입되는 것을 가정하였다.

\subsection{2. 공간 격자계}

$\mathrm{CFD}$ 모사 대상 다지관의 전체 격자는 범용적으로 사용되는 tetra 형상을 사용하였으며, 벽면 근처에서는 보다 정확한 해 상도와 수치해석을 위해 프리즘(prism) 격자를 사용하였다. 경계면에 프리즘 격자를 적용한 것은 벽면과 유체사이 경계층 에서 발생하는 급격한 유속 변화를 효율적으로 모사하기 위해 격자를 상대적으로 작게 배열하기 위해서이다.

\subsection{3. 지배 방정식}

$\mathrm{CFD}$ 모사를 위한 지배방정식은 연속, 운동량 및 에너지 방 정식이며 식(2), (3) 및 (4)과 같이 표현된다.

$$
\begin{aligned}
& \frac{\partial \rho}{\partial t}+\frac{\partial}{\partial x_{j}}\left(\rho u_{j}\right)=0 \\
& \begin{aligned}
& \frac{\partial}{\partial t}\left(\rho u_{j}\right)+\frac{\partial}{\partial x_{j}}\left(\rho u_{j} \rho u_{i}\right)=-\frac{\partial P}{\partial x_{j}}+\frac{\partial \tau_{i j}}{\partial x_{j}}+S_{u} \\
& \frac{\partial}{\partial t}(\rho H-P)+\frac{\partial}{\partial x_{j}}\left(\rho U_{j} H\right) \\
&=\frac{\partial}{\partial x_{j}}\left(k \frac{\partial T}{\partial x_{j}}\right)-\frac{\partial}{\partial x_{j}}\left(u_{j} \tau_{i j}\right)+S_{T}
\end{aligned}
\end{aligned}
$$

여기서, $\rho=$ 밀도, $u_{i, j}=$ 속도, $P=$ 압력, $\mu$ =점성계수, $H=$ 전엔탈피, $h=$ 정적엔탈피, $T=$ 온도, $\tau_{i j}=$ 응력텐서를 나타 낸다.

상태방정식 $\rho=\rho(P, T)$, 점성계수와 변형률의 함수로서 응 력텐서의 응력-변형률 관계, 그리고 $h=h(P, T)$ 가 방정식에 추가되었으며, 난류유동은 와점성(Eddy Viscosity)이 추가되 고 방정식은 레이놀즈 평균 물리량에 대해 해석하였다.

\subsection{4. 난류 모델링}

본 해석에서의 난류 모델링은 $k-\epsilon$ 난류모델을 사용하였으 며, 난류 모델은 평균성분과 변동성분을 도입하여 수정된 수 
송 방정식(Transport equation)의 해를 구하기 위한 수단이다. 전엔탈피는 평균운동에너지(Mean kinetic energy)와 난류운동 에너지(Turbulent kinetic energy)를 포함한다. 여기서 난류운 동에너지는 식 (5)와 같이 정의된다. ${ }^{16)}$

$$
k=\frac{1}{2} \overline{u^{2}}
$$

$k$ 는 난류운동에너지이며, 속도 변동의 분산으로 정의되고, 차원은 $\left(\mathrm{L}^{2} \mathrm{~T}^{-2}\right)$ 즉 $\mathrm{m}^{2} / \mathrm{s}^{2}$ 이다. $\epsilon$ 은 난류 소산율(Turbulence eddy dissipation)이고 단위시간당 $k$ 의 차원을 갖는다. 즉, $\left(\mathrm{L}^{2} \mathrm{~T}^{-3}\right), m^{2} / s^{3}$ 이다. $k-\epsilon$ 모델은 기본 방정식에 2 개의 변수가 추가된다. $k-\epsilon$ 모델은 난류 점성을 난류운동에너지와 소산율 을 이용하여 다음과 같이 가정한다.

$$
\mu_{t}=C_{\mu} \rho \frac{k^{2}}{\epsilon}
$$

여기서, $\mu_{t}$ 는 난류 점성이며, $C_{\mu}$ 는 상수이다.

\section{3. 결과 및 토의}

\section{1. 유량 분배 실측 실험 결과}

다음 Fig.5는 각각 K_막여과시설 6계열(unit) 중 1계열, 2계 열과 6계열의 유량 분배 실측을 나타낸 것이다. $\mathrm{X}$ 축은 헤더 배관의 길이를 첫 번째 유입구부터 거리로 나타낸 것이다. 총

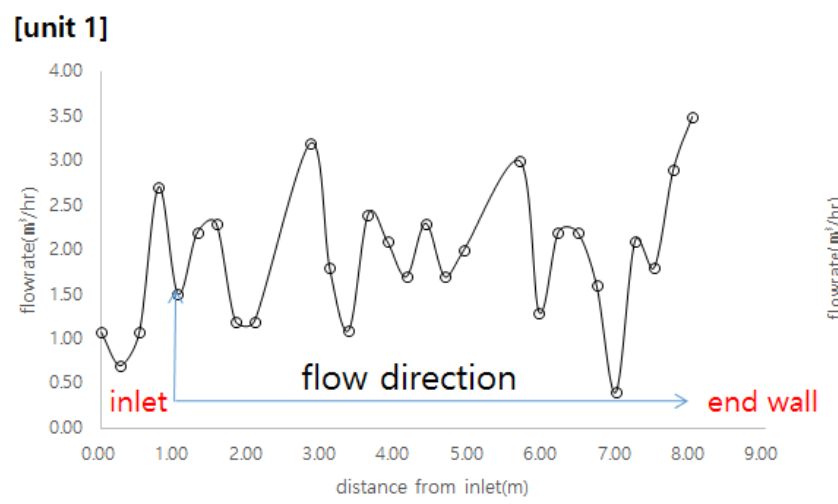

\section{[unit 6]}

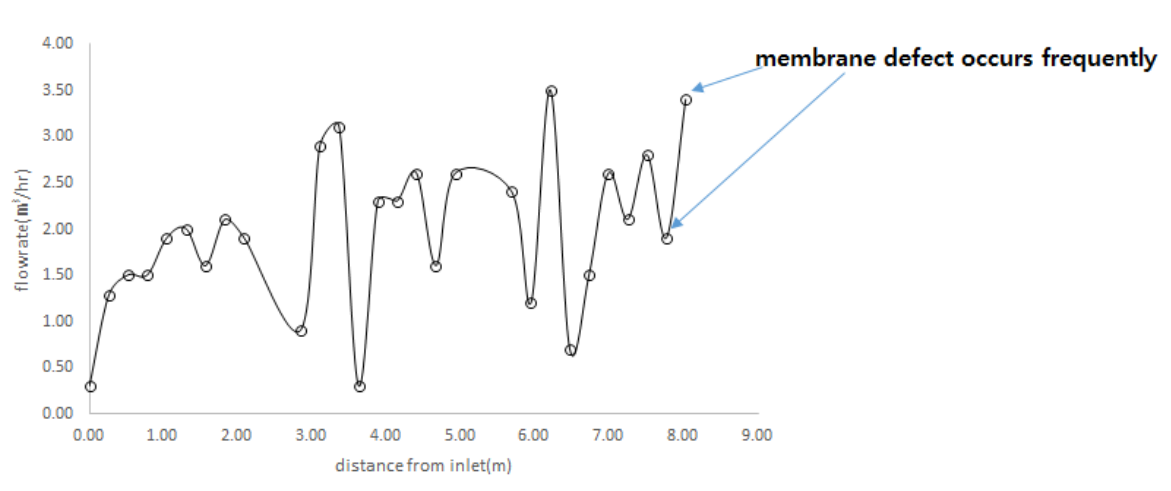

헤더 배관의 길이 $9.17 \mathrm{~m}$ 에서 유입구부터 첫 번째 분지관까지 의 거리 $0.77 \mathrm{~m}$ 를 빼고 표시하였다. $\mathrm{Y}$ 축은 헤더 배관에서 각 막 모듈로 유입되는 유량을 초음파 유량계로 측정한 데이 터를 표시하였다. 각 $\bigcirc$ 이 위치한 28 개의 분지관을 통해 모 듈로 유입되는 유량을 나타낸다. 6계열의 경우(unit 6) 27번 째 및 28 번째 막 모듈은 자주 막의 파단이 발생하던 위치를 표시하였다. 유입구에서 멀어질수록 분지관을 통해 막 모듈 로 유입되는 유량이 증가하는 것으로 실측되었다. 앞서 언급 한 바와 같이 초음파 유량계 측정에 있어서 정확한 유량 값 을 측정할 수 있는 조건이 갖추어지지 않았고, 막 여과공정 이 운전되는 동안 잦은 유량 변동 및 역세가 주기적으로 수 행되어 정확한 데이터를 얻는 데에는 한계가 있었다. 그럼에 도 불구하고 유입구에 가까운 분지관보다 헤더 배관 끝으로 갈수록 유출 유량이 증가하는 것을 알 수 있었다. 유입구 첫 번째 분지관과 헤더 배관 끝단에 위치한 분지관으로부터의 유출 유량은 약 3 배 정도의 차이가 나타났다. 이는 6 계열의 27 번째 및 28 번째 잦은 막의 파단 발생과 무관하지 않은 것 으로 판단된다.

다음 Fig. 6은 2.3절에서 언급한 바와 같이 초음파 유량계로 취득한 데이터를 이용하여 최소-최대 정규화 및 선형회귀분 석을 한 결과를 도시한 것이다. $\mathrm{X}$ 및 $\mathrm{Y}$ 축 데이터는 각 무차원 거리 및 무차원 유량으로 표시하였으며, 1 차식과 3 차식으로 각각 선형회귀분석 식을 나타내었다. 결정계수 $\left(\mathrm{R}^{2}\right)$ 이 다소 낮 지만 양의 기울기를 가지므로 분지관 유량의 상승추세를 명확

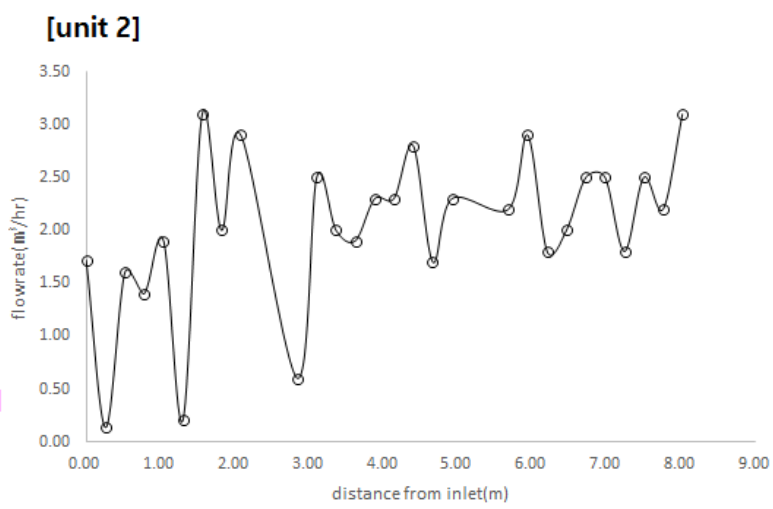

Fig. 5. Flow distribution measurement results. 


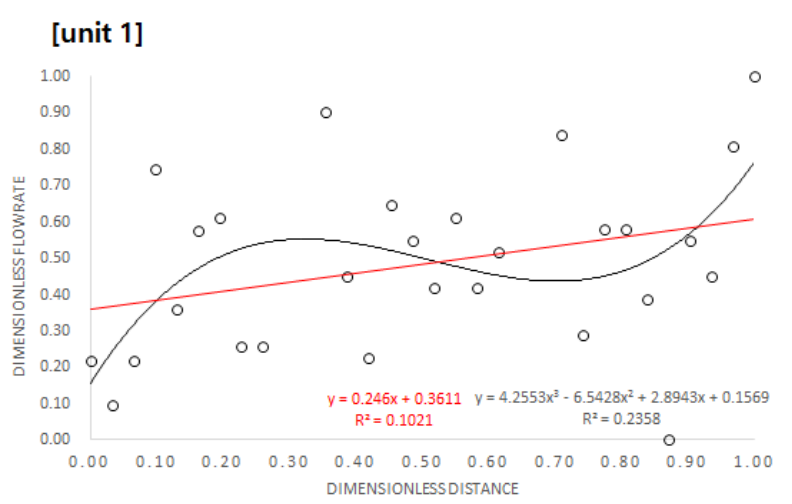

[unit 6]

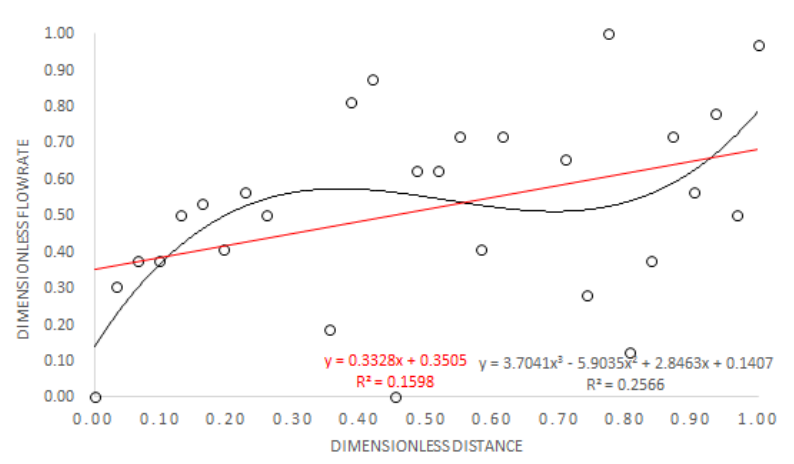

Fig. 6. Statistical analysis results.

히 알 수 있다. 3 차 다항식을 활용하여 회귀분석을 결과에서 는 무차원거리 0.3 과 0.75 지점에서 각각 두 개의 변곡점이 발생하는 것을 알 수 있었다. 무차원거리 $0 \sim 0.3$ 에서는 상승하 다가 $0.3 \sim 0.75$ 에서는 다소 하강하며 이후 급속히 상승하는 것 으로 나타났다.

\subsection{CFD 모사를 통한 원인 분석}

다음 Fig.7은 실제 운전 중인 막 여과 공정의 다지관(Fig. 4(a))을 대상으로 유입유량이 $55 \mathrm{~m}^{3} / \mathrm{hr}$ 인 경우를 CFD 기법으 로 모사한 결과를 나타내었다. 유입구 측은 왼쪽이며, 원수의 주된 흐름은 왼쪽에서 오른쪽으로 흐른다. Fig. 7(a)는 속도장 을 contour로 나타내었으며, (b)는 vector로 표시한 것이다. 그 림에서 나타낸 바와 같이 유입구에서 가까운 쪽은 상대적으로 유속이 빠르다(약 $1.5 \mathrm{~m} / \mathrm{sec})$. 이에 반해 헤더 배관 끝으로 갈 수록 유속이 $0.3741 \mathrm{~m} / \mathrm{sec}$ 이하로 낮아지는 것이 보여지고 있 다. 그러나 이러한 유속 분포로는 헤더 배관 끝단 부근에서 분지관 유출 유량이 많은 것을 설명할 수는 없다.

다음 Fig. 8은 CFD 모사를 통해 각 지관에서 유출되는 유 량을 그래프로 표현한 것이다. 초음파 유량계를 이용하여 실 측한 유량과 비슷한 양상을 보이고 있다. 실측값과는 약 $10 \%$ 정도의 차이를 보이고 있으나 헤더 배관 유입구 근처에 비해 끝단으로 갈수록 분지관을 통해 유출되는 유량이 증가하는 양상을 명확히 보이고 있다. 실측과 유사하게 유입구 첫 번 째 분지관과 헤더 배관 끝단에 위치한 분지관으로부터의 유
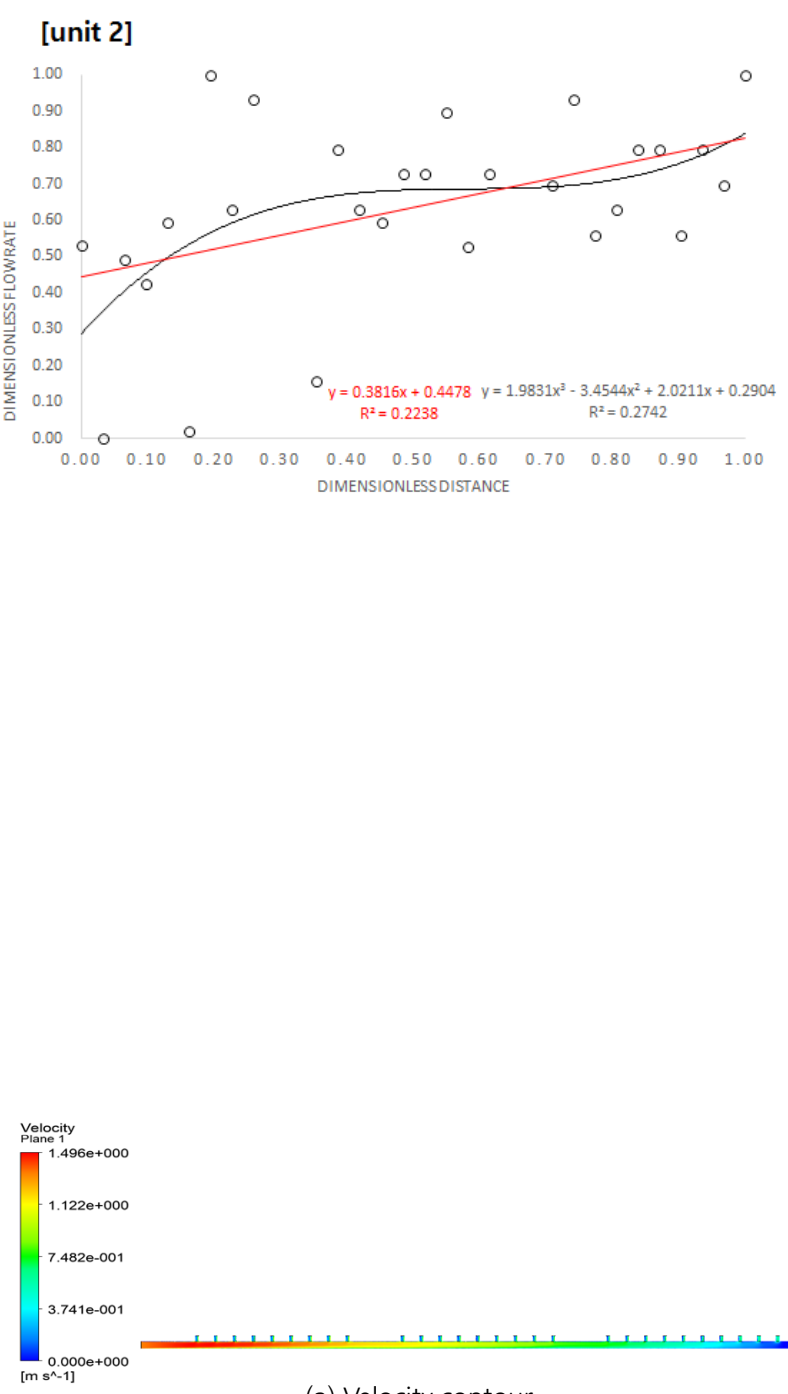

(a) Velocity contour

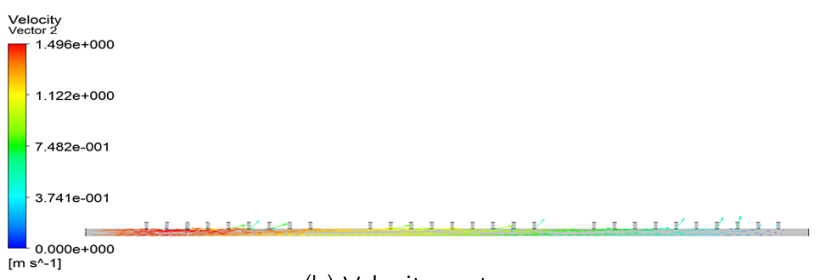

(b) Velocity vector

Fig. 7. CFD simulation results for actual manifold pipe.

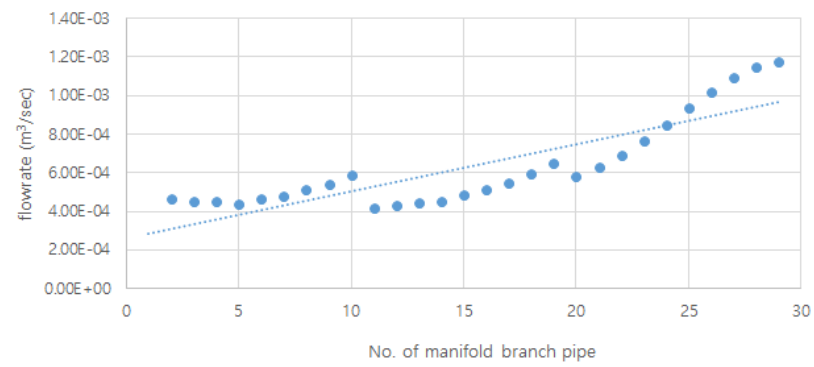

Fig. 8. Flow distribution from CFD simulation result (actual manifold pipe). 


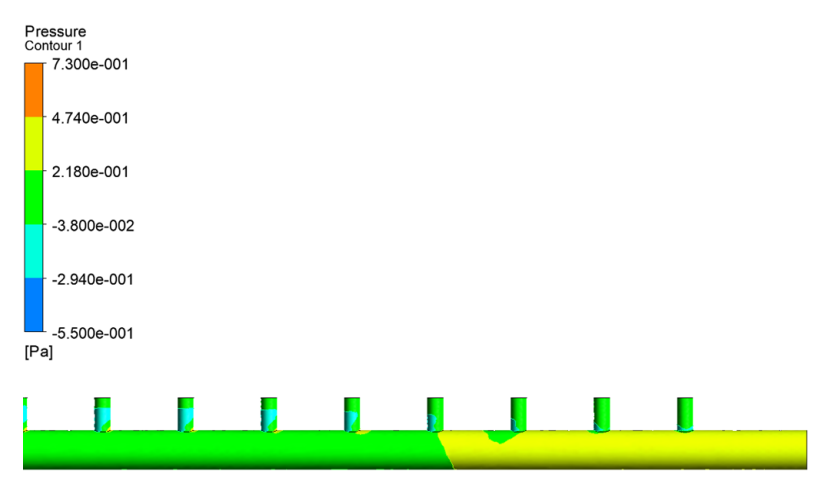

Fig. 9. Pressure distribution for actual manifold pipe.

출 유량은 약 3 배 정도의 차이도 확인되었다. 특히 무차원 거리상에서 0.3 과 0.75 가 되는 위치에서 순간적으로 유출 유 량이 감소하는 양상은 3 차 다항식으로 선형회귀분석을 한 그래프에서 변곡점을 보이는 위치와 거의 동일한 양상이 나 타났다. 그러나 이러한 유속 및 유출 유량분포로는 헤더 배 관 끝단 부근에서 분지관 유출 유량이 많은 원인을 설명할 수는 없다.

이에 다음 Fig.9과 같이 헤더 배관 끝단의 압력분포를 면밀 히 검토하였다. 그림에서는 헤더 배관 오른쪽 끝단 9 개 분지 관 주변의 압력분포를 확대하여 본 것이다. 그림에서 나타난 바와 같이 오른쪽 헤더 배관 끝으로 갈수록 상대적으로 압력 이 높아지는 것을 알 수 있다. Legend의 색깔로 판단하건대 끝단에 위치한 $25,26,27$ 및 28 번째 분지관에서의 압력이 다 른 다지관에 비해 약 3 배정도 높은 압력 분포를 나타낸다. 막 모듈의 저항을 대표하는 투수계수 $(K)$ 는 거의 동일하다고 가 정한다면 이는 'Darcy의 법칙'으로 그 원인을 귀결시킬 수 있 다(식 (7) 참조). 막 모듈을 사이에 두고 유입구의 압력과 유출 구의 압력의 차를 $d h$ (수두손실)표현할 때 이 수두손실은 헤더 배관 유입구측의 분지관보다 헤더 배관 끝단에 위치한 분지관 이 약 2 배 정도 크게 나타나고 있다. 그러면 다음과 같은
Darcy 법칙 수식을 이용한다면 여재로 작용하는 막 모듈을 통과하는 유속 $V$ 가 커지므로 연속 방정식에 의해 헤더 배관 끝단으로 갈수록 유량이 증가하게 된다.

$$
V=\frac{Q}{A}=-K \frac{d h}{d L}
$$

여기서, $V$ 는 막 모듈 통과유속, $Q$ 는 막 모듈 통과 유량, $A$ 는 막 모듈의 통수 단면적, $K$ 는 막 모듈의 투수계수, $d h$ 는 각 막 모듈의 유입구와 유출구의 압력차(차압), $d L$ 은 막 모듈의 길이로 나타낼 수 있다.

이에 병열로 배치된 막 모듈 헤더 배관에서 유입구보다 끝 단으로 갈수록 분지관 유출유량이 커지는 이유는 각 막 모듈 을 사이로 발생하는 차압이 헤더 배관 끝으로 갈수록 높기 때문인 것으로 설명할 수 있다. 앞서 에너지 공학 분야에서 제안되었던 단면적을 축소한 헤더 배관(Tapered header)을 적 용하여 균일한 유속분포를 도모하는 방법은 ${ }^{11)}$ 실제 수처리 막 모듈 배관 구조에는 적용이 불가하며, 오히려 각 모듈간의 차 압의 분포를 증가시켜 유량의 분균등을 심화할 수 있다.

\section{3. 헤더 배관 확장을 통한 유량 균등화 제고}

앞서 언급한 바와 같이 본 연구의 부가적인 목적 중 하나는 실제 운전 중인 막 여과 공정을 대상으로 유량을 균등화시키 기 위해 필요한 지관과 헤더 배관의 비를 제시하고자 하였으 며, 또한 헤더 배관이 관수로임을 고려하여 헤더 배관에서의 Reynolds No.와 다지관 유량의 균등 정도와의 관계를 밝히고 자 하였다. 문헌 연구와 실측을 통해 헤더 배관에 유입되는 유량(유속)에 따라 유입구에서 가까운 분지관의 유량이 관 말 단 분지관의 유량에 비해 상대적으로 큰 경우와 작은 경우로 구분할 수 있다(Fig. 10 참조).

본 연구의 대상이 된 $\mathrm{K}$ 정수장 실제 막 여과시설의 헤더 배관 내 유입 유속이 빠르기 때문에 관 말단 분지관에서의

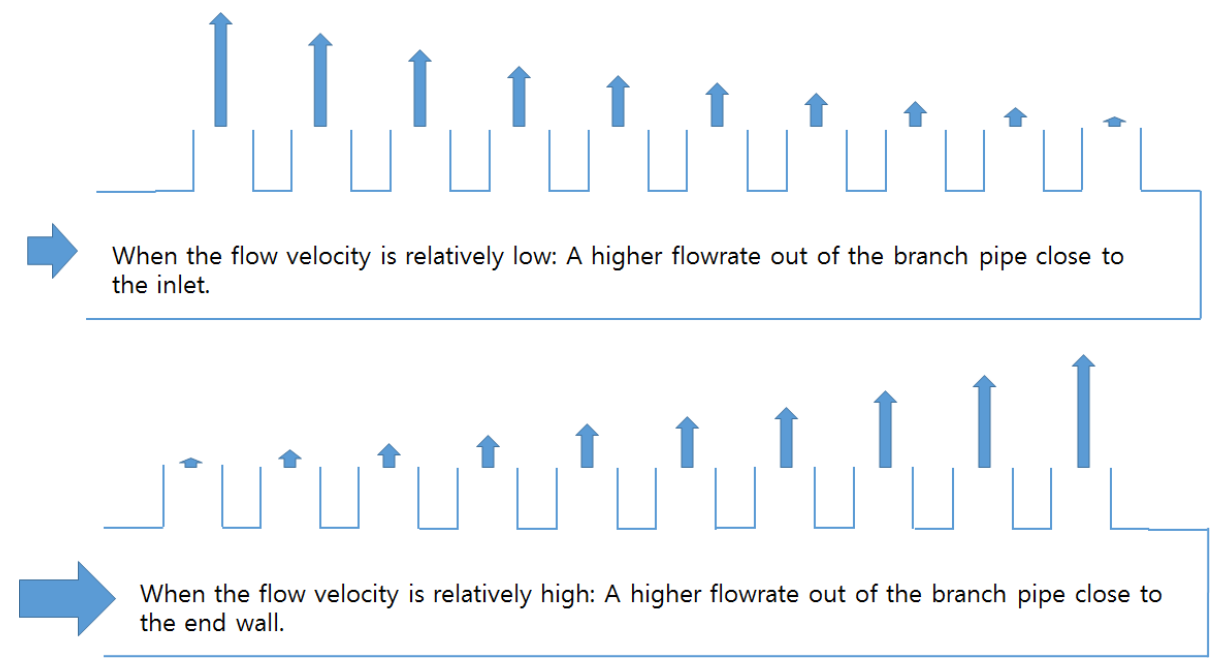

Fig. 10. Relationship between header pipe inlet velocity and flow distribution pattern. 

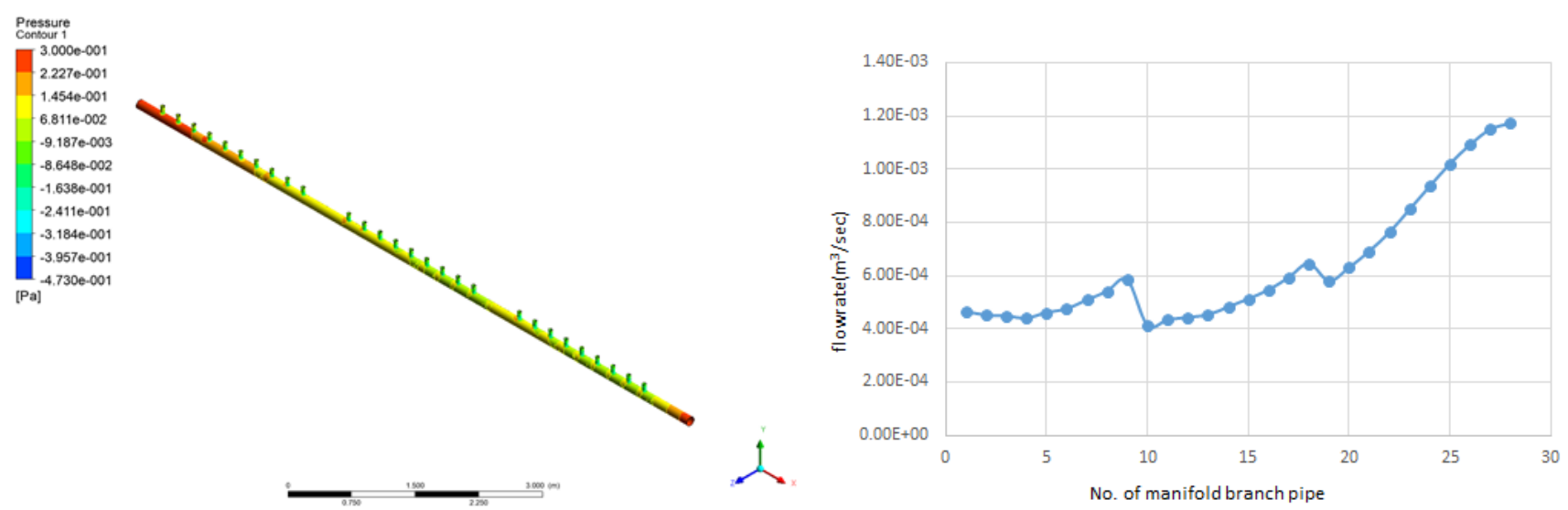

(a) CFD simulation results for actual manifold pipe $\left(\frac{\sum a}{A}=4.861, a\right.$ : branch pipe cross-sectional area, $A$ : header pipe cross-sectional area)
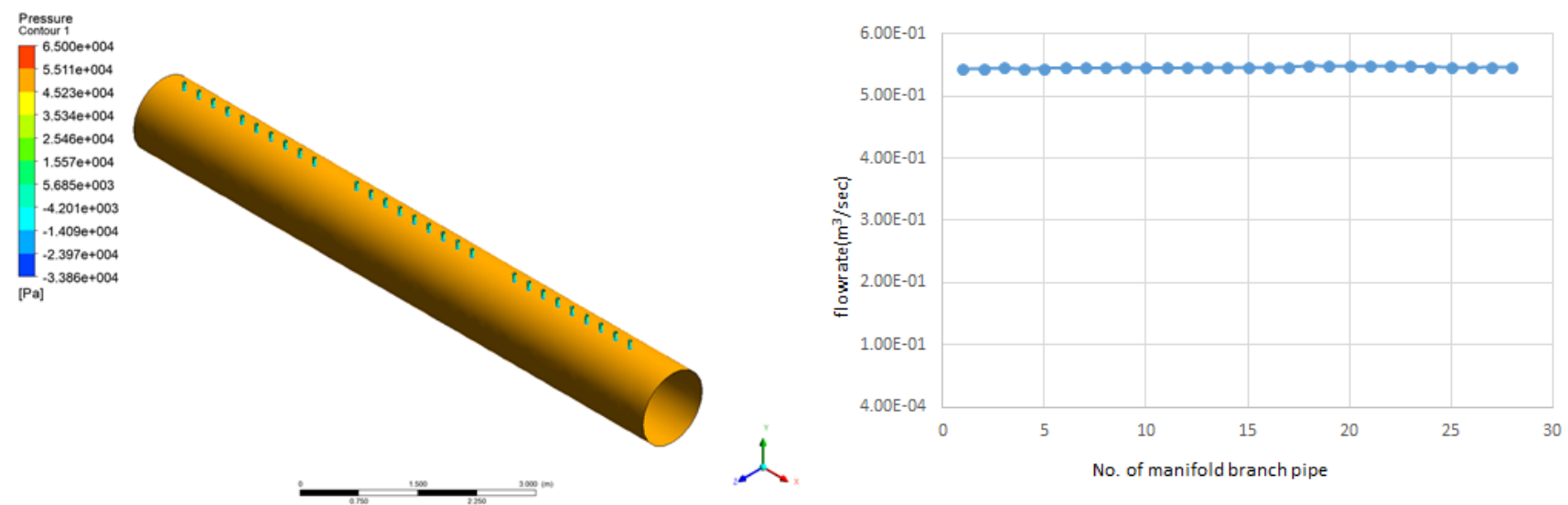

(b) CFD simulation results of manifold pipe with enlarged diameter $\left(\frac{\sum a}{A}=0.116\right)$

Fig. 11. Flow distribution evenness through expansion of header pipe.

유출 유량이 큰 것을 알 수 있었다. 연속 방정식에 의해 만약 헤더 배관의 직경을 증가시키면 관 내 유속이 감소할 것이며, 이에 각 분지관에서 유출되는 유량이 균등해지는 조건을 찾을 수 있겠다는 가정 하에 헤더 배관의 직경을 점차 증가시키면 서 CFD 모사를 수행한 결과 다음 Fig. 11과 같은 결과를 도출 하였다. 그림에서 나타낸 바와 같이 실제 막 여과 배관 (a)의 경우 $\left(\frac{\sum a}{A}=4.861\right)$ 와 비교하여 분지관의 단면적의 합과 헤 더 배관의 통수 단면적의 비가 약 80 배 정도 감소할 경우 $\left(\frac{\sum a}{A}=0.061\right)$ 각 막 모듈로 유입되는 유량이 거의 균등한 것을 확인 할 수 있었다.

또한 헤더 배관으로의 유입유량 $55 \mathrm{~m}^{3} / \mathrm{hr}$ 을 배관의 통수 단 면적으로 나누어 Reynolds No.를 구하게 되면 Fig. 11의 (a)와 (b)의 경우 각각 162,120 과 2,026 로 계산된다. 헤더 배관의 관경을 이보다(Fig. 11(b)의 기준보다) 더 증가시켜 관내 유속 및 Reynolds No.를 감소시키게 되면 유량 분배의 현사이 반대 로 유입구와 가까운 분지관에서 상대적으로 많은 유량이 유출 되는 현상이 나타났다. 통상적으로 관수로에서 Reynolds No.
가 4,000 이상인 경우 난류로, 2,400 이하인 경우 층류로 구분 하며 그 사이의 값을 가지는 흐름을 천이류로 구분한다. 본 연구에서는 대상이 된 하나의 실제 막 여과 시설을 대상으로 상기와 같은 결론을 얻었지만, 헤더 배관상의 흐름이 천이류 및 층류인 경우 각 분지관에서 막 모듈로 유입되는 유량을 균등화 시킬 수 있을 것으로 판단할 수 있다. 그러나 Fig. 11(b)에서 보다시피 기계적인 설치 및 공간의 문제를 고려한 다면 헤더 배관의 크기를 증가시켜 유량의 균등화를 제고하는 방안은 많은 기술적인 제약사항 있을 것으로 사료되며, 초기 투자비 및 운전에 소요되는 에너지 비용 또한 증가할 것으로 판단된다.

\section{4. 결론}

본 연구에서는 실제 정수처리에 적용되고 있는 외압식 저 압막(정밀여과막, Microfiltration) 여과 공정을 대상으로 각 모 듈로 유입되는 유량의 균등 정도를 실측하고, 전산유체역학 (Computational Fluid Dynamics, CFD)을 이용하여 그 원인을 
밝히고자 하였다. 또한 유량을 균등화시키기 위해 필요한 지 관과 헤더 배관의 비를 제시하고자 하였으며, 헤더 배관이 관 수로임을 고려하여 헤더 배관에서의 Reynolds No. 와 다지관 유량의 균등 정도와의 관계를 밝히고자 하였다. 이에 다음과 같은 결론을 얻을 수 있었다.

1) 초음파 유량계를 이용한 실측과 CFD 모사 결과로부터 본 연구의 대상이 된 막 여과시설의 막 모듈 배관 구조에서는 유입구에 가까운 분지관보다 헤더 배관 끝으로 갈수록 유출 유량이 증가하는 양상을 확인 할 수 있었다. 유입구 첫 번째 분지관과 헤더 배관 끝단에 위치한 분지관으로부터의 유출 유량은 약 3 배 정도의 차이가 나타났다.

2) 연구 대상이 된 병열로 배치된 막 모듈 헤더 배관에서 유입구보다 끝단으로 갈수록 분지관 유출유량이 커지는 이유 는 각 막 모듈을 사이로 발생하는 차압이 헤더 배관 끝으로 갈수록 높기 때문이었다.

3) 연구대상이 된 실제 막 여과 배관을 대상으로 분지관의 단면적의 합과 헤더 배관의 통수 단면적의 비를 약 80 배 정도 감소할 경우 각 분지관에서 막 모듈로 유입되는 유량이 거의 균등한 것을 확인 할 수 있었다. 이에 헤더 배관상의 Reynolds No.로 판단하자면, 관내 흐름이 천이류 및 층류인 경우 (Reynolds No.가 대략 4,000 이하) 각 분지관에서 막 모듈 로 유입되는 유량을 균등화 시킬 수 있을 것으로 판단할 수 있다.

4) 그러나 기계적인 설치 및 공간의 문제를 고려한다면 헤 더 배관의 크기를 증가시켜 유량의 균등화를 제고하는 방안은 많은 기술적인 제약사항 있을 것으로 사료되며, 초기 투자비 및 운전에 소요되는 에너지 비용 또한 증가할 것으로 판단된 다. 또한 다른 막 여과 정수장을 대상으로 본 연구에서 제시된 기준의 확장성에 대해서도 확인이 필요한 바이다.

\section{Acknowledgement}

이 논문은 2021년도 대구시 물산업 구매연계 기술개발사업 'RO 시스템 운영 효율 향상을 위한 균등분배 기술개발' 연구 사업의 지원을 받아 수행되었습니다.

\section{References}

1. C. W. Kim, S. M. Yoon, S. S. Kim, J. E. Kim, N. S. Park, A study on the appropriateness evaluation of membrane module piping design using CFD simulation technique, J. Korean Soc. Environ. Eng., 40(3), 103-110(2018).

2. Y. L. Li, K. L. Tung, CFD simulation of fluid flow through spacer-filled membrane module: selecting suitable cell types for periodic boundary conditions, Desalination, 233(1-3), 351-358(2008).

3. B. G. Ko, J. H. Na, D. H. Nam, K. H. Kang, C. Y. Lee, Fouling mitigation for pressurized membrane of side-stream MBR process at abnormal operation condition, J. Korean Soc. Environ. Eng., 38(6), 323-328(2016).

4. J. Hokins, S. A. Deowan, V. Panten, A. Figoli, R. R. Huang, E. Drioli, Membrane bioreactor (MBR) technology- a promising approach for industrial water reuse, Procedia Eng., 33, 234-241(2012).

5. Y. T. Ahn, S. T. Kang, B. U. Bae, C. Y. Lee, W. T. Lee, Direct measurement of cake fouling potentials by powdered activated carbon during microfiltration of surface water, Desalin. Water Treat., 57(16), 7449-7455(2016).

6. S. H. Kim, S. Y. Moon, C. H. Yoon, S. K. Yim, J. W. Cho, Role of coagulation in membrane filtration of wastewater for reuse, Desalination, 173(3), 301-307(2005).

7. P. I. Shen, The effect of friction on flow distribution in dividing and combining flow manifold, J. Fluids Eng., 114(1), 121-123(1992).

8. S. H. Choi, S. Shin, Y. I. Cho, The effect of area ratio on the flow distribution in liquid cooling module manifolds for electronic packaging, Int. Comm. Heat Mass Transf., 20(2), 221-234(1993).

9. A. B. Datta, A. K. Majumdar, Flow distribution in parallel and reverse flow manifolds, Int. J. Heat Fluid Flow, 2(4), 253-262(1980).

10. A. Eguchi, M. Kuragasaki, Y. Sueoka, K. Koga, Performance improvement on ACDEFLO headbox of paper machine, Mitsubishi Heavy Ind. Techn. Rev., 25(3), 191-196 (1988).

11. J. C. Hong, J. B. Riggs, Flow distribution in tapered, rectangular cross section manifolds, J. Chin. Inst. Chem. Engrs., 18(4), 193-202(1987).

12. A. Muhana, D. R. Novog, Validation of fluent for prediction of flow distribution and pressure gradients in a multi-branch header under low flow conditions, in Proceedings of the 16th International Conference on Nuclear Engineering, ICONE16, Florida, USA(2008).

13. W. Ding, Application of CFD in membrane technique, Universität Duisburg-Essen, Duisburg, Germany(2012).

14. P. A. C. Chang, J. S. Pierre, J. Stumper, B. Wetton, Flow distribution in proton exchange membrane fuel cell stacks, J. Power Sources, 162(1), 340-355(2006).

15. J. H. Kim, H. D. Kim, H. J. Lee, S. Y. Hwang, A CFD analysis of gas flow through an ultrasonic meter, in Proceedings of the Korean Society of Mechanical Engineers 2003 conference, pp. 998-1003(2003).

16. J. I. Oh, J. W. Choi, J. L. Lim, D. G. Kim, N. S. Park, A study on hydraulic modifications of low-pressure membrane inlet structure with CFD and PIV techniques, J. Korean Soc. Environ. Eng., 37(11), 607-618(2015). 


\section{Declaration of Competing Interest}

The authors declare that they have no known competing financial interests or personal relationships that could have appeared to influence the work reported in this paper.

\section{Authors and Contribution Statement}

\section{SeokHyun Jang}

Department of Civil Engineering and Engineering Research Institute, Gyeongsang National University, Master Candidate, ORCID(D) 0000-0003-0648-3528: Conceptualization, Methodology, Validation, Writing - original draft.

\section{Sukmin Yoon}

Department of Civil Engineering and Engineering Research Institute, Gyeongsang National, Professor, ORCID (10 0000-0002-5304-1207: Conceptualization, Methodology, Validation, Writing - original draft.

\section{Si-Yeon Kim}

Department of Civil Engineering and Engineering Research Institute, Gyeongsang National University, Master Candidate, ORCiD(D) 0000-0002-9111-450X: Conceptualization, Methodology, Validation, Writing - original draft.

\section{Young-Joo Lee}

K-water Research Institute, Principal Researcher, ORCID(C) 0000-0002-4947-0076: Conceptualization, Methodology, Validation, Writing - original draft.

\section{No-Suk Park}

Department of Civil Engineering and Engineering Research Institute, Gyeongsang National University, Professor, ORCID \0000-00025396-1636: Conceptualization, Methodology, Validation, Writing - original draft. 